\title{
Water Pollution and Treatment Technologies
}

\author{
D. Harikishore Kumar Reddy* and S.M. Lee \\ Department of Environmental Engineering, Kwandong University, Gangneung, Republic of Korea
}

Keywords: Water Pollution; Wastewater treatment; Adsorption; Photocatalysis; Desalination

\section{Water Pollution}

Water is a source of life and regarded as the most essential of natural resources. Water covers most of our; however, approximately $98 \%$ of this water is seawater and is unusable for drinking because of the high concentration of salt. About $2 \%$ of the planet's water is fresh, but 1.6 $\%$ is locked up in polar ice caps and glaciers. Another $0.36 \%$ is found underground in aquifers and wells. Therefore, only about $0.036 \%$ of the planet's total water supply is accessible in lakes and rivers.

WHO/UNICEF survey states that in 45 developing countries, women and children bear the primary responsibility for water collection in the vast majority $(76 \%)$ of households. This is time not spent working at an income-generating job, caring for family members, or attending school [1].

Furthermore, existing freshwater resources are gradually becoming polluted and unavailable due to human or industrial activities. The increasing contamination of freshwater systems with thousands of industrial and natural chemical compounds is one of the key environmental problems facing humanity worldwide [2]. The everincreasing world populations and rapidly advancing industrialization is causing more demand than ever for the dwindling supply of water, which makes it precious in more and more countries. In some parts of the world, water is a crucial commodity. Recently, a paper published in Nature indicated that $80 \%$ of the world's population is exposed to high levels of threat to water security [3].

A growing number of contaminants are entering water supplies from industrialization and human activity like heavy metals, dyes; pharmaceuticals; pesticides, fluoride, phenols, insecticides, pesticides and detergents. In the case of pharmaceuticals, personal care products, hormones, pesticides, and other chemical compounds that are released into the water supply. Unprecedented health hazards are coming to light that did not previously exist resulting in an increased need for additional legislature [2]. Many water pollutants remain to be addressed, due to rapid industrialization new chemical compounds are continuously being developed and brought to the market and sooner or later they will emerge into the aquatic systems. Additionally water borne pathogenic microorganisms are ubiquitous throughout the world. These pathogenic microorganisms enter waterways through untreated sewage, storm drains, septic tanks, runoff from farms, and from various industries, especially the tanning and meat packaging industries. Major sources of water pollution are showed in Figure 1.

Emerging pollutants detected in water may have adverse effects on human health and aquatic ecosystems. Clean water that is free of toxic chemicals and pathogens is essential to human health. On top of these concerns, contamination of water is a big concern after a natural disaster. Natural disasters(e.g., tsunamis, earthquakes, hurricanes, floods, and volcanoes)can influence water quality on a grand scale.

In the coming decades, water scarcity may leads to social and political instability, water wars and diseases, unless new ways to supply clean water are found. Increased public awareness has led governments and organizations worldwide to issue strict water pollution regulations. Nowadays there is a continuously increasing worldwide concern for the development of wastewater treatment technologies.

\section{Progress in Water Treatment Technologies}

In view of the aforesaid problems, recent attention has been focused on the development of more effective, lower-cost, robust methods for wastewater treatment, without further stressing the environment or endangering human health by the treatment itself [4]. Extensive studies have been undertaken to find economically feasible alternatives for water and wastewater treatment. A number of methods such as coagulation, membrane process, adsorption, dialysis, foam flotation, osmosis, photo catalytic degradation and biological methods have been used for the removal of toxic pollutants from water and wastewater [5] However, their applications have been restricted by many factors, such as processing efficiency, energy requirement, engineering expertise, economic benefit and infrastructure, all of which precludes their use in much of the world.

Due to the complex nature of the chemical mixtures present in wastewater, conventional wastewater treatment is not always sufficient to remove the entire contaminant load. Disinfection steps such as ozonation and chlorination have been introduced to control human

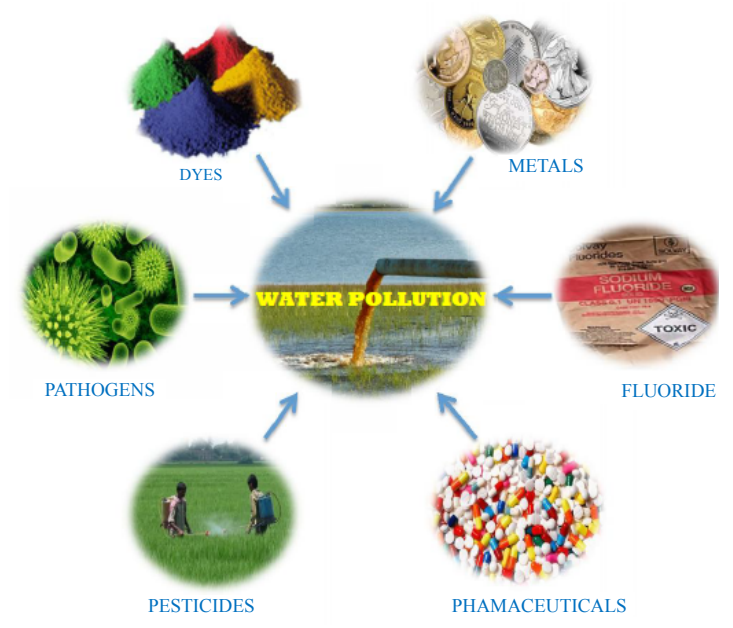

Figure 1: The major sources of water pollution.

*Corresponding author: D. Harikishore Kumar Reddy, Department of Environmental Engineering, Kwandong University, Gangneung, Republic of Korea, E-mail: chemkishore@gmail.com

Received April 27, 2012; Accepted April 28, 2012; Published April 30, 2012

Citation: Kumar Reddy DH, Lee SM (2012) Water Pollution and Treatment Technologies. J Environ Anal Toxicol 2:e103. doi:10.4172/2161-0525.1000e103

Copyright: () 2012 Kumar Reddy DH, et al. This is an open-access article distributed under the terms of the Creative Commons Attribution License, which permits unrestricted use, distribution, and reproduction in any medium, provided the original author and source are credited. 
pathogens. These advanced treatment processes are very effective at eliminating most unwanted pathogens and many chemicals [6]. In recent years, the semiconductor photo catalytic process, a low-cost, environmental friendly and sustainable treatment technology to align with the "zero" waste scheme in the water/wastewater industry has been widely studied [7]. This advanced oxidation technology is able to remove persistent organic compounds, arsenic metal ions and microorganisms from the water. At present, the main technical barrier that impedes its commercialization is the post-recovery of the catalyst particles after water treatment.

Adsorption is one of the most effective processes of advanced wastewater treatment technologies, that industry and academic researchers widely employ for the removal of various pollutants. Activated carbon is one of the most widely investigated adsorbent in water treatment process [8]. In recent years, the "adsorption" process has become more popular as "biosorption" which uses biomaterials as the adsorbent, for contaminated water treatment $[9,10]$.However this process has not been widely employed on an industrial scale for wastewater treatment. Also the application of magnetic adsorbent technology for separation of pollutants in water has received considerable attention in recent years. During the past decade, great efforts have been devoted to the preparation of a variety of magnetic composites/materials for wastewater treatment. Magnetic adsorbents are an attractive solution for metallic and dye pollutants, particularly due to the simple magnetic separation process.

The recovery of resources from wastewater is a matter of increasing global importance and, as such, it has attracted much research interest. However, as far as the contained nutrients are concerned, there has been relatively limited transfer of important research finding into practical operational outcomes. Desalination is a logical option in a world where fresh water is increasingly scarce and many cities are located near the ocean. The only issue is reducing energy consumption, because that is the main cost. Everyone who works on desalination has as an aim to reduce this as low as possible.

Due to different types of pollutants different techniques have been developed and employed for wastewater treatment. This invariably increases the cost of obtaining clean water. The operation cost is also considerable when the developed process has to reach poor people especially in underdeveloped countries, where the water scarcity is very high. In addition, safe water awareness is still not adequately understood by most of the people around the world.

The research and developments carried in wastewater treatment methods have to reach global audience as early as possible. This will happen only if science opens the gates to exchange information free of cost between the developed and developing countries. This is possible only with the Open Access Publishers', Journal of Environmental \& Analytical Toxicology from the OMICS Publishing Group providing a good platform form for environmental and analytical scientists to publish their research in open access journal. Especially in the research areas of water and wastewater treatment, the published articles should be easily available to the researchers, which is very necessary to raise awareness of people around the globe.

\section{Conclusions}

Clearly, there is an urgent need to create awareness for pressing environmental problems and to develop solutions in close cooperation between science, governments, industry, and other relevant stakeholders. The research and development in the area of water treatment has to reach the real applications where needed as early as possible.

\section{References}

1. WHO/UNICEF Joint Monitoring Programme (JMP) for Water Supply and Sanitation (2010) Progress on Sanitation and Drinking-Water.

2. Schwarzenbach RP, Escher BI, Fenner K, Hofstetter TB, Johnson CA, et al. (2006) The challenge of micropollutants in aquatic systems. Science 313:1072-1077.

3. Vörösmarty CJ, Mclntyre PB, Gessner MO, Dudgeon D, Prusevich A, et al. (2010) Global threats to human water security and river biodiversity. Nature 467: 555-561.

4. Shannon MA, Bohn PW, Elimelech M, Georgiadis JG, Marinas BJ, et al. (2008) Science and technology for water purification in the coming decades. Nature 452: $301-310$

5. Pontius FW (1990) Water quality and treatment. (4thedn), New York: McGrawHill, Inc.

6. Escher B, Leusch F, Chapman H (2011) Bioanalytical tools in Water Quality Assessment. IWA Publishing.

7. Chong MN, Jin B, Chow CWK, Saint C (2010) Recent developments in photocatalytic water treatment technology: A review. Water Res 44: 2997-3027.

8. Rao MM, Reddy DH, Venkateswarlu P, Seshaiah K (2009) Removal of mercury from aqueous solutions using activated carbon prepared from agricultural byproduct/waste. J Environ Manage 90: 634-643.

9. Reddy DHK, Ramana, DKV, Seshaiah K, Reddy AVR (2011) Biosorption of $\mathrm{Ni}(\mathrm{II})$ from aqueous phase by Moringaoleifera bark, a low cost biosorbent Desalination 268: 150-157.

10. Reddy DHK, Seshaiah K, Reddy AVR, Lee SM (2012) Optimization of Cd(II) $\mathrm{Cu}(\mathrm{II})$ and $\mathrm{Ni}(\mathrm{II})$ biosorption by chemically modified Moringaoleifera leaves powder. Carbohydr Polym 88: 1077-1086. 